\title{
Capsule 24 Hour Sustained Release Dosage Form
}

National Cancer Institute

\section{Source}

National Cancer Institute. Capsule 24 Hour Sustained Release Dosage Form. NCI

Thesaurus. Code C68944.

A capsule designed to release active and/or inert ing redient(s) slowly so as to achieve a constant circulating concentration of the ing redient over a 24 hour time interval. 